\title{
The Analysis of the Culture-Related Contents in an Indonesian English Textbook
}

\author{
Ulya Safira Riadini ${ }^{1}$, Bambang Yudi Cahyono ${ }^{2}$ \\ ${ }^{1}$ Universitas Negeri Malang, Indonesia. E-mail: safiraariadini@gmail.com \\ 2Universitas Negeri Malang, Indonesia.E-mail: bambang.yudi.fs@um.ac.id
}

\begin{tabular}{ll}
\hline ARTICLE INFO & ABSTRACT \\
\hline Keywords: & $\begin{array}{l}\text { This research analyzed the presentation of culture-related contents of the } \\
\text { tenth-grade senior high school English textbook. The textbook was published }\end{array}$ \\
culture-related contents, & by the Ministry of Education and Culture of Republic Indonesia. The written \\
cultural information, & texts that contain cultural information were identified by employing content \\
English textbook, senior & analysis based on Cortazzi \& Jin (1999) three sources of cultural information, \\
high school & and coded under the eight categories by Byram (1993). Cortazzi \& Jin (1999) \\
& categorization is used to portray the presentation of culture-related contents \\
& in the English textbook. The written texts were classified into those sources, \\
& and Byram (1993) checklist was used in the procedure of the content analysis \\
& mentioned earlier. The scope of the cultural content and how it meets the \\
& needs of cultural teaching in English language teaching are revealed in this \\
checklist. The findings showed that the EFL textbook not only reflects the \\
target cultures, but also source cultures and international cultures. The \\
materials present source cultures as the most frequently depicted cultures and \\
the international cultures are the least frequently depicted cultures. In \\
hol: \\
lijeltal.v5i2.711
\end{tabular}

How to cite:

Riadini, U. S. \& Cahyono. B. Y. (2021). The Analysis of the Culture-Related Contents in an Indonesian English Textbook. Indonesian Journal of English Language Teaching and Applied Linguistics, 5(2), $285-295$.

\section{Introduction}

As culture and language competence are closely connected, the ability to communicate needs the knowledge of thinking and acting properly in accordance with the language associated with the culture. Therefore, the idea of integrating language and culture became a topic to be discussed in the recent researches during the last ten years; especially at the issue of how culture is represented in the English textbook (Faris, 2014; Gunantar, 2017; Kim \& Paek, 2015; Muhsen Al Harbi, 2017; Setyono \& Widodo, 2019; Silvia, 2015). The integration of language teaching and culture brings a number of advantages (Crozet \& Liddicoat, 1997). One of the advantages is that students will gain eternal benefits from their language learning 
experience. Moreover, students who get the knowledge of a particular culture can develop their positive attitude in the community and become more tolerant of other cultures (Nguyen, 2017). In addition, students can learn to speak and write in a way that is culturally appropriate. Brown (2001) also stated that students who can better engage themselves in the use of language are those who are exposed to the culture associated with the language.

One of the ways to embody culture and language is by designing an English textbook with cultural contents in it. Kim \& Paek (2015) stated that to develop students' intercultural communicative competence, the learning activities provided in an English textbook need to be designed by inserting more cultural contents. Their research in Korea revealed how cultures are represented in English textbooks. Firstly, in three broad aspects of culture, they discovered inequities in the representation of culture-related contents. Secondly, the contents on intercultural interaction $(\mathrm{ICl})$, which includes materials on the cultural awareness were seriously under-represented. Lastly, the material on the 'little c,' which refers to cultural traditions, appeared to be more predominant in the textbooks. Other studies found that integrating various sources of cultural information develops students' cultural awareness (Faris, 2014; Silvia, 2015). Muhsen Al Harbi (2017) described that an English textbook as a guide that shapes the image of the English language and culture. By using the English textbook that has been integrated with cultures in the EFL teaching and learning process, students will indirectly and automatically internalize the contents to meet the competence. Therefore, the cultural contents represented in an English textbook and how they meet the needs of cultural teaching in English language teaching and learning become an important and interesting topic to be analyzed.

A textbook would be any book that is written and published for educational purposes or that is used as a teaching aid in the classroom (Lappalainen, 2011). The textbook provides directions for the teaching and learning process. The ideas on how to plan and teach the lessons are provided in the textbook according to the curriculum applied. Thus, the textbook provides content and activities that would portray what happens in the classroom. That is why various efforts in the context of improving the quality of education have always been carried out through developing the teaching materials; in this case, it is the textbook. Muhsen Al Harbi (2017) in his research on evaluating EFL textbooks for the secondary stage in Saudi Public schools, stated that, "Good textbooks are supposed to fulfill many expectations. They should follow the national curriculum, consider the expectations, needs, and hopes of the teachers and the pupils and enable language learning." In addition, Opoku-Amankwa et al., (2011) assured that "textbooks should not simply aim at providing a body of knowledge. Rather, they should stimulate the pupils' interest, develop creativity and interactive learning, and create cultural awareness." The textbook's material, in particular, should be appropriate for students and aligned with national educational goals (Faris, 2014). As a result, culture also plays a crucial role in the development of the contents of the textbook because culturallyoriented textbooks enable the students to develop intercultural communicative competence. As found by Setyono \& Widodo (2019) in their research on an EFL textbook for Indonesian senior high school students, four themes of multicultural values are found in the textbook, namely respect for the cultures of various ethnic and religious groups; indigenous people's cultures; conflict-avoidance and peace with all ways of life and nature; and appreciation of creative cultural products. Setyono \& Widodo (2019) also emphasized that "The implications of this textual study suggest that as English plays an increasingly important role as a global 
lingua franca, multicultural materials from outer and expanding circle countries need to be added to English language teaching (ELT) textbooks."

According to the preceding description, it is reasonable to assume that to design a good English textbook, the writer should consider including a balanced representation of cultures. It means that the textbook materials should include culturally relevant content from the target culture, source culture, and international culture as proposed by Cortazzi \& Jin (1999). Such cultural representations are aimed at helping students in perceiving and categorizing social contexts they may encounter, highlighting both cultural skills and cultural awareness. As known, a textbook is still chosen to be the major resource in the English language teaching and learning process which is expected to cover everything, including the culture-related contents. Therefore, an evaluation is needed. One of the ways is to employ a checklist which actually varies greatly in terms of the importance and specificity focused on culture in English textbooks. Byram (1993) checklist focuses on cultural contents. Byram looked at the degree to which a textbook focuses on each of the areas mentioned in Table 1. A research study by Gunantar (2017) revealed that Byram's checklist is considered sufficient and comprehensive as it proved that the English textbook evidently focused on Indonesian culture. Gunantar (2017) stated that, "This set of a checklist is driven from the idea of cultural learning and teaching as an integral part of language education."

Combining Cortazzi \& Jin's (1999) cultural information and Byram's (1993) checklist could be an attempt to evaluate an English textbook in detail as a way to support the development of teaching and learning materials as well as improving the quality of education. Besides, the results of previous researches are rarely used this method to evaluate an English textbook. Therefore, to fill the gap, the present research will analyze how cultural contents are presented in the materials of the senior high school English textbook based on the explanation above. The written texts that contain cultural information were identified by employing content analysis based on Cortazzi \& Jin's (1999) three sources of cultural information, and coded under the eight categories by Byram (1993). The research question is stated "How are the culture-related contents portrayed in the English textbook for the senior high school?"

\section{Literature Review}

Cultural contents are described as data or information containing cultural values, such as symbols or signs, letters, and words, as well as figures or pictures. Based on Cortazzi \& Jin (1999), the materials in English textbooks are divided into three categories in relation to their cultural contexts: source culture, target culture, and international culture. The culture of countries where English is spoken as a first language, such as the United States, the United Kingdom, and Australia, is included in the target culture materials. The majority of the material is about life in countries where English is the native language. According to Kim \& Paek (2015), integrating target culture elements into textbooks aims to increase students' enthusiasm and behavior toward language learning. Source culture, on the other hand, refers to the learners' own culture as material. In the case of Indonesia, the materials primarily portray Indonesian society and culture, ensuring that learners are familiar with the content and have a good chance to understand it. Lastly, international culture materials come from both English- and non-English-speaking countries and reflect a variety of cultures. 
Textbooks in a second or foreign language are often expected to include elements of the target culture. However, actually, the target culture is not always represented; some textbooks include a wide range of English-speaking cultures, while others include nonEnglish-speaking cultures, emphasizing more international uses of the language. Therefore, textbook evaluation checklists are often used to assess the extent and quality of the representation. Checklists differ widely in the emphasis and detail given to the role of culture in EFL textbooks (Cortazzi \& Jin, 1999). Byram's (1993) checklist is one of the most comprehensive lists of standards for textbook evaluation. It focuses on cultural material, as shown in Table 1. It explores the degree to which a textbook has an emphasis on each of the areas, as well as the manner in which it does so. Therefore, by integrating Cortazzi \& Jin's (1999) cultural information and Byram's (1993) checklist, this research attempts to identify how cultural contents are portrayed in the materials of the senior high school English textbook in order to determine whether or not the English textbook has been designed with culture-related contents. It is expected to find that the culture-related contents will meet the needs of students in improving their intercultural communicative competence (ICC) and cultural awareness.

Table: 1 Categorization of the Cultural Contents

\begin{tabular}{|c|c|}
\hline No & Category \\
\hline 1 & Social identity and social groups (social class, regional identity, ethnic minorities) \\
\hline 2 & Social interaction (differing levels of formality) \\
\hline 3 & Belief and behavior (moral, religious beliefs, daily routines) \\
\hline 4 & $\begin{array}{l}\text { Social and political institutions (state institutions, health care, law and order, social } \\
\text { security, local government) }\end{array}$ \\
\hline 5 & Socialization and the life cycle (families, schools, employment, rites of passages) \\
\hline 6 & $\begin{array}{l}\text { National history (historical and contemporary events seen as markers of national } \\
\text { identity) }\end{array}$ \\
\hline 7 & National geography (geographic factors seen as being significant by members) \\
\hline 8 & $\begin{array}{l}\text { Stereotypes and national identity (what is "typical," symbols of national } \\
\text { stereotypes) }\end{array}$ \\
\hline
\end{tabular}

(Byram, 1993 cited in Cortazzi \& Jin, 1999, p. 203)

\section{Research Methodology}

A qualitative content analysis under the perspective of textbook evaluation is employed to reveal how the culture-related contents are portrayed in an English textbook entitled "Bahasa Inggris" (Revision edition) for Tenth Grade EFL students of Senior High School, published in 2017 by the Ministry of Education and Culture of Republic Indonesia. Hsieh \& Shannon (2005) defined qualitative content analysis as a research tool for subjective interpretation of text data content using a structured classification process of coding and defining themes or patterns. To make it more comprehensible, quantitative analysis in the form of percentages is used. The procedure of the research is as follows.

First, the contents analyzed include reading texts, dialogues, and quotes. This step is in line with Chelimsky's (1989) statement that content analysis is a structured methodology for obtaining and organizing information in a structured format that enables analysts to make inferences about the characteristics and context of written and other documented materials. The second is selecting units of analysis in the English textbook. By this chance, this research will analyze the overall chapters in the textbook. 
The textbook is identified by using Cortazzi \& Jin's (1999) three sources of cultural information. They are target culture materials, source culture materials, and international culture materials. The analysis was focused on the cultural contents proposed by Byram (1993). The categorization of the cultural contents is shown in Table 1. Cortazzi \& Jin's (1999) categorization is used to portray the presentation of culture-related contents in the English textbook. The written texts were classified into those sources, and Byram's (1993) checklist was used in the procedure of the content analysis. The scope of the cultural contents and how it meets the needs of cultural teaching in English language teaching are revealed in this checklist.

An English textbook written by Utami Widiati, Zuliati Rohmah, and Furaidah was used as the research object. ((PDF) Kelas 10 SMA Bahasa Inggris - Buku Siswa | Afifah Ghaitsani Academia.Edu, n.d.) The four language skills and three language components sections were presented in the 15 chapters of the textbook and distributed in 220 pages based on the basic competencies stated to develop students' communicative competence. This textbook is arranged based on the approach in the 2013 curriculum that is the genre-based approach which emphasizes students' ability in understanding and producing texts in various genres. The reason to use this textbook is that it is provided by the Ministry of Education and Culture of Republic Indonesia to be used in all Senior High Schools all over Indonesia as the main resource in the English language teaching and learning process.

\section{Findings}

The English textbook entitled "Bahasa Inggris" (Revised edition) for the Tenth Grade EFL students of Senior High School consists of fifteen chapters. The textbook provides materials for four language skills (listening, speaking, reading, and writing) and the English components (vocabulary, grammar, and pronunciation) in each chapter. Every chapter contains written texts which included all the reading texts, dialogues, and quotes. The source culture materials refer to the students' own culture as content, based on Cortazzi \& Jin's (1999) categorization. The target culture materials, meanwhile, include the cultural materials of a country where the first language is spoken in English. Lastly, the international culture materials present a wider variety of cultures where English is not used as first or source language (L1) or second language (L2). Table 2 shows the availability of that three cultural information (source culture, target culture, and international culture) which represented the cultural contents in the English textbook completed with the frequency $(f)$ and percentage (\%) from each cultural information.

Table: 2 The Depiction of Cultural Contents in the English Textbook

\begin{tabular}{|c|c|c|c|c|c|c|c|c|}
\hline \multirow[t]{2}{*}{ Category code } & \multicolumn{2}{|c|}{$\begin{array}{l}\text { Target } \\
\text { culture }\end{array}$} & \multicolumn{2}{|c|}{$\begin{array}{l}\text { Source } \\
\text { culture }\end{array}$} & \multicolumn{2}{|c|}{$\begin{array}{c}\text { International } \\
\text { culture }\end{array}$} & \multirow[t]{2}{*}{ Total (f) } & \multirow{2}{*}{$\begin{array}{c}\text { Total } \\
(\%)\end{array}$} \\
\hline & $f$ & $\%$ & $f$ & $\%$ & $\mathrm{~F}$ & $\%$ & & \\
\hline Code 1 & 1 & 11 & - & & - & - & 1 & 3 \\
\hline Code 2 & 3 & 33 & 2 & 13 & - & - & 5 & 19 \\
\hline Code 3 & - & - & 1 & 6 & - & - & 1 & 3 \\
\hline Code 4 & - & - & - & - & - & - & - & - \\
\hline Code 5 & 2 & 22 & 1 & 6 & - & - & 3 & 11 \\
\hline Code 6 & 1 & 11 & 4 & 26 & 1 & 50 & 6 & 23 \\
\hline Code 7 & 1 & 11 & 2 & 13 & - & - & 3 & 11 \\
\hline Code 8 & 2 & 22 & 5 & 33 & 1 & 50 & 8 & 30 \\
\hline Total & 9 & $35 \%$ & 15 & $58 \%$ & 2 & $7 \%$ & 26 & $100 \%$ \\
\hline
\end{tabular}


After the fifteen chapters were analyzed, the result showed that the cultural contents were found in all of the chapters in the English textbook. Based on Cortazzi \& Jin's (1999) cultural information, the source cultures are the most frequently depicted materials, and the international culture is least presented materials. As shown in Table 2, the source cultures were presented in 15 written texts, while only two written texts present international cultures. Not all sources of cultural information appeared in each chapter. For example, in Chapter 1 , there are written texts which present the source and target culture, but none of them present international cultures. Moreover, not all cultural categories from each source of cultural information are presented in this English textbook. As shown in the table, cultures in Code 8 (stereotypes and national identity) are the most frequently represented in the textbook. The result of the research above revealed an imbalanced presentation of the cultural information in this textbook.

Meanwhile, the spread of the source of culture in this English textbook can also be seen from the percentage of each type of culture. As shown in Table 2, there was a difference in the number of cultural contents presented in each type of culture. From the largest percentage, $58 \%$ are the source culture, $35 \%$ are the target culture, and only $7 \%$ are the international culture. Details of the identification of each cultural information will be described in the following parts.

\subsection{Source Culture}

In the total of fifteen chapters, target culture dominates the cultural contents included in this English textbook. From the fifteen data, five of them indicated cultures from the source language ( $\left.L_{1}\right)$ that describes stereotypes and national identities. As stated in Table 1, source culture refers to a specific symbol or sign of national stereotypes, national identity, famous people, famous monuments, and famous folktales. For example, "The Legend of Malin Kundang" becomes one of the Indonesian famous folktales.

Moreover, this folktale also indicates what is mentioned in the third category, belief, and behavior. This category measures the cultural materials that convey specific attitudes, values, and beliefs while also guiding people's social actions. It was identified that this folktale led students to know about the particular perceptions, values, and beliefs that would guide their behaviors.

The story of Malin Kundang built people's perspectives that if we do not obey our parents then misfortunes and distress would befall our lives. However, it is based on people belief. They may believe the stories or not. It is all about the perspectives to the stories and on the reality that exists today. It is important to emulate the meaning contained in the story. This conviction also happens in the other two written texts.

Next, source cultures from the sixth category (national history) became the second most presented in this English textbook after the eighth category (stereotypes and national identity). It categorized the culture from the source language (L1) in terms of national history, historical and contemporary events seen as markers of national identity. A passage told us about "Heroes Day" is one of the examples. This story commemorates the Battle of Surabaya that took place in 1945, where pro-independence Indonesian soldiers and militias fought against British and Dutch soldiers as a part of the Indonesian National Revolution. 
Unfortunately, there is no written text which contained cultural information from the source language (L1) in the first and the fourth category. However, in fact, it is also important for students to know the cultures of both categories. To know how cultures are implemented in these two categories helps the students to shape their national identity. The first category defines cultures from the aspects of social identity and social groups. Social status, regional identity, and ethnic minorities are all covered. Meanwhile, the fourth category refers to the cultures of state institutions, health care, law and order, social welfare, and local government.

\subsection{Target Culture}

The second most presented culture in the English textbook is the target cultures. Cultures that are described in social interaction, the second category, are the most frequently presented in this textbook. In terms of levels of formality, there are two written text materials in the form of an email as examples. The first email showed social interaction between penpals. The sender, Hannah, introduced herself to her friend informally, and she is a native. It can be seen from her sentence "I know your name from my friend, Caroline. She told me that you sent her an email telling her that you would like to have more pen pals from the US. "Another proof was when she said that she likes music - mostly classical music and folk music, and sports, which are basketball and tennis. This text represents classical music, folk music, basketball, and tennis as kinds of target cultures related to the fifth category, socialization, and the life cycle. It covers family, school, employment, media, ceremonies, art, food, relationship, and sport. Meanwhile, the second email, it showed a different level of formality since the sender was the entertainment management and it was a formal announcement. Moreover, these two emails are practices for students to differentiate the social function, the text structure, and the language features based on the context.

Another result obtained from the study was that the target culture in the first, sixth, and seventh categories are not frequently presented in this English textbook. These categories are presented only in one written text. Moreover, there were no target cultures in the third category (belief and behavior) and the fourth category (social and political institutions) presented in this English textbook.

\subsection{International Culture}

The presentation of this cultural information is limited in this English textbook. There is only one written text which presents the international cultures, in the sixth (national history) and the eighth category (stereotypes and national identity). As its definition, the international culture materials present a wider variety of cultures where English is not used as L1 or L2. The written text entitled "Issumboshi" can be an example. It is a Japanese national famous folktale, and Japan is one of the countries that does not use English as the L1 or L2.

Based on the result of the study, all of the sources of cultural information are presented in this English textbook. Even though there are imbalances, all of the existing data are sufficient to meet the cultural needs that must be implemented into the student's textbook. Moreover, cultures where English is used as the second language are also presented in this English textbook. A descriptive text entitled "Taj Mahal" is one of the examples. This text illustrates the culture of India in terms of its national history and famous monument as its national identity. Moreover, India has proclaimed to use English as the second language. As we know, there are various non-English speaking countries around the world using English as an 
international language, and India is one example. The sample of the depiction of cultural content in the English textbook is shown in Table 3.

Table: 3 The Sample of the Depiction of Cultural Content in the English Textbook

\begin{tabular}{|c|c|c|c|c|c|c|}
\hline \multirow{2}{*}{ Chapter } & \multirow{2}{*}{ Topic } & \multirow{2}{*}{ Text } & \multirow{2}{*}{ Section } & \multirow{2}{*}{ Page } & \multicolumn{2}{|c|}{ Cultural Information } \\
\hline & & & & & Type & Code \\
\hline \multirow[t]{3}{*}{1} & \multirow{3}{*}{$\begin{array}{l}\text { Talking } \\
\text { about self }\end{array}$} & \multirow{3}{*}{$\begin{array}{l}\text { Hello, Alia! Let me introduce } \\
\text { myself. My name is Hannah. } \\
\text { I know your name from my } \\
\text { friend, Caroline. She told me } \\
\text { that you sent her an email } \\
\text { telling her that you would like } \\
\text { to have more pen pals from the } \\
\text { US. I'd really like to be your E- } \\
\text { pal. You sound really cool! } \\
\text {...I like music - mostly classical } \\
\text { music and folk music - but I } \\
\text { don't play an instrument. I like } \\
\text { sports, especially tennis and } \\
\text { basketball... }\end{array}$} & \multirow{3}{*}{$\begin{array}{l}\text { Reading: } \\
\text { email }\end{array}$} & \multirow[t]{3}{*}{4} & Target Culture & TC.1(1) \\
\hline & & & & & Target Culture & TC.2(1) \\
\hline & & & & & Target Culture & TC.5(1) \\
\hline 4 & $\begin{array}{l}\text { Which one is } \\
\text { your best } \\
\text { gateway? }\end{array}$ & $\begin{array}{l}\text { Tanjung Puting Nasional Park is } \\
\text { an internationally famous } \\
\text { ecotourism destination, ... }\end{array}$ & $\begin{array}{l}\text { Reading: } \\
\text { Descripti } \\
\text { ve text }\end{array}$ & 53 & $\begin{array}{l}\text { Source } \\
\text { Culture }\end{array}$ & SC.7(1) \\
\hline \multirow[t]{2}{*}{9} & \multirow[t]{2}{*}{$\begin{array}{l}\text { The Battle } \\
\text { of Surabaya }\end{array}$} & \multirow{2}{*}{$\begin{array}{l}\text { On } 10 \text { November, Indonesia } \\
\text { celebrates Hari Pahlawan or } \\
\text { Heroes Day in remembrance of } \\
\text { the Battle of Surabaya... } \\
\ldots \text { The defiant Bung Tomo is } \\
\text { the well-known revolutionary } \\
\text { leader ... }\end{array}$} & \multirow{2}{*}{$\begin{array}{l}\text { Reading: } \\
\text { Recount } \\
\text { Text }\end{array}$} & \multirow[t]{2}{*}{123} & $\begin{array}{l}\text { Source } \\
\text { Culture }\end{array}$ & SC.6(1) \\
\hline & & & & & $\begin{array}{l}\text { Source } \\
\text { Culture }\end{array}$ & SC.8(2) \\
\hline \multirow[t]{2}{*}{12} & \multirow[t]{2}{*}{ Issumboshi } & \multirow{2}{*}{$\begin{array}{l}\text { Once upon a time there was an } \\
\text { old couple who didn't have a } \\
\text { child. They lived in a small } \\
\text { house near the village forest. } \\
\text { "Please give us a child," they } \\
\text { asked God everyday... }\end{array}$} & \multirow{2}{*}{$\begin{array}{l}\text { Reading: } \\
\text { Narrativ } \\
\text { e text }\end{array}$} & \multirow[t]{2}{*}{157} & $\begin{array}{l}\text { International } \\
\text { culture }\end{array}$ & IC.6(1) \\
\hline & & & & & $\begin{array}{l}\text { International } \\
\text { culture }\end{array}$ & IC.8(1) \\
\hline
\end{tabular}

\section{Discussion}

This research examined the way in which culture is reflected in the textbook used for teaching English as a foreign language (EFL). In this case, it is found that the EFL textbook reflects not only the target cultures but also source cultures and international cultures. As a result, an intercultural competence formed by the textbook exposure may not only encourage identity development but also promote the understanding of the identities of others and an element of stabilization in a rapidly changing world.

According to Cortazzi \& Jin (1999), there are EFL textbooks created for specific countries at the national level that represent the source culture rather than target cultures. This is in line with the findings of this research. The English textbook entitled "Bahasa Inggris" (Revised edition) for the Indonesian Tenth Grade EFL students of Senior High School, is primarily Indonesian rather than a target culture. It is about Indonesian history, stereotypes, socialization, and other categories which are discussed in English. The reason is that such 
materials are typically intended to help students be conscious of their own cultural identity. Research was written by Silvia (2015) also has a similar finding. Relatively, in the two prescribed English textbooks being analyzed, source culture is the most prominently portrayed, followed by target culture, culture-free and international target culture materials. Silvia (2015) stated that source culture or local culture has a probability to help students to activate their local knowledge. However, it did not happen in Faris (2014) research of cultural content analysis of an English textbook for senior high school grade three in Cianjur, Indonesia. In comparison to the source culture and international culture, the target culture is heavily portrayed in this English textbook (Faris, 2014). Thus, the culture-related content contained in the English textbook should be practical for the students. By doing so, students gain a better understanding of the language's cultural context since they are familiar with the cultural representations.

However, this textbook is designed as a manifestation of implementing the 2013 curriculum. The curriculum which is designed to carry out the 21st century education recognizes the importance of high school graduates to master English to convey ideas beyond the Indonesian terms and to absorb ideas from outside the country that can be used for the nation's benefit. Setyono \& Widodo (2019), in their research related to multicultural values, argued that, "School graduates are expected to be global citizens who respect religious, social and cultural values; enjoy working hard; and think creatively to make contributions at both national and international levels." Therefore, content related to the target cultures and the international cultures is also presented or integrated into the materials in the analyzed English textbook.

The variety of the cultural contents led to the importance of multicultural education for students due to the use of English as international communication. Hernandez (2001) stated that multicultural education is a process in which students develop ways of perceiving and evaluating to behave in different cultural systems. Multicultural education produces skilled and dignified generations, reflects cultural values, participates in shaping the nation's character, contributes to the development of national identity, and participates in the preservation of national culture (Oktavianti. et al., 2017). Understanding multicultural diversity also means accepting the diversity of cultural expressions, both domestic and foreign. As for the cultural materials to be included in EFL textbooks, Alptekin (2002) suggests that the instructional materials and activities should include local, goal, and foreign contexts that are familiar and important to the lives of language students. Intercultural communicative competencies can be improved, according to Bryam (1997), when students are exposed to a culturally diverse environment in which they internalize the norms of various cultures. As found in Silvia's (2015) research, the first intercultural communicative competence (basic cultural awareness) was achieved in the two prescribed English textbooks. In line with the present research, it was found that the English textbook supports multicultural education by serving materials containing information on source cultures, target cultures, and international cultures.

\section{Conclusion}

The result of the analysis shows that all the sources of cultural information found in the English textbook entitled "Bahasa Inggris" (revised edition) are represented through written texts in the form of source culture, target culture, and international culture. They were 
presented in the English textbook materials frequently in reading, speaking, writing, and vocabulary sections. Among three sources of cultural information, the result showed that cultural contents dealing with the source culture were most frequently presented, in $58 \%$. Then, cultural contents in target culture were presented in $35 \%$. However, the finding shows that the cultural contents in international culture were seriously under-represented through written texts in the English textbook. It was only presented in $7 \%$. This causes an imbalance in the cultural presentation of this English textbook. However, the English textbook aimed to develop the students' their cultural awareness, including the cultures from the other countries, without ruling out the cultures of Indonesia.

Overall, the materials related to culture in this English textbook are well represented to be integrated into the English language teaching and learning process. Moreover, based on the analysis result, the English textbook entitled "Bahasa Inggris" (revised edition) for Senior High School contained cultural contents based on Cortazzi \& Jin's (1999) source of cultural information is recommended to be used by the English teachers. The findings of this study also suggest to future researchers who are interested in undertaking a similar study to identify the gap and explore other elements in the field of EFL textbook review. They could perform a similar analysis in a different English textbook to see if the textbook's materials contain cultural content based on the other indicators and to learn about the authors' strategy for portraying cultural contents in the textbook.

\section{References}

Alptekin, C. (2002). Towards Intercultural Communicative Competence in ELT. ELT Journal, 56(1), 57-64. https://doi.org/10.1093/elt/56.1.57

Brown, H. D. (2001). Teaching by Principle and Interactive Approach to Language Pedagogy. New York: Longman.

Byram, M. (1993). Language and culture: The Need for Integration. In M. Byram (Ed.), Germany: Its Representation in Textbooks for Teaching German in Great Britain (pp. 316). Frankfurt: Diesterweg.

Byram, M. (1997). Teaching and Assessing Intercultural Communicative Competence. Clevedon: Multilingual Matters.

Chelimsky, E. (1989). Content Analysis : A Methodology for Structuring and Analyzing Written Material. United States General Accounting Office.

Cortazzi, M., \& Jin, L. (1999). Cultural mirrors: Materials and methods in the EFL Classroom. In E. Hinkel (Ed.), Culture in Second Language Teaching and Learning (pp. 196-219). Cambridge: Cambridge University Press.

Crozet, C., \& Liddicoat, A. J. (1997). Teaching Language, Teaching Culture. Australian Review of Applied Linguistics. Series S, 14. Applied Linguistics Association of Australia, Clayton. https://doi.org/10.1075/aralss.14.01cro

Faris, I. N. I. (2014). Cultural Content Analysis of an English Textbook for Senior High School Grade Three in Cianjur, West Java. Journal of English and Education, 2(2), 14-25.

Gunantar, D. A. (2017). Textbooks Analysis: Analyzing English as a Foreign Language (Efl) Textbooks From the Perspective of Indonesian Culture. Language Circle: Journal of Language and Literature, 11(2), 173-182. https://doi.org/10.15294/lc.v11i2.9590 
Hernandez, H. (2001). Multicultural education: A Teacher's Guide to Linking Context Process, and content (2nd ed). New York: Merril Prentice Hall.

Hsieh, H. F., \& Shannon, S. E. (2005). Three Approaches to Qualitative Content Analysis. Qualitative Health Research, 15(9), 1277-1288. https://doi.org/10.1177/1049732305276687

Kim, S. Y., \& Paek, J. (2015). An Analysis of Culture-Related Content in English Textbooks. Linguistic Research, 32(1) (special-edition), 83-104. https://doi.org/10.17250/khisli.32..201507.005

Lappalainen, T. (2011). Presentation of the American Culture in EFL Textbooks: An Analysis of the Cultural Content of Finnish EFL Textbooks for Secondary and Upper Secondary Education. Department of Languages, University of Jyväskylä.

Muhsen Al Harbi, A. A. (2017). Evaluation Study for Secondary Stage EFL Textbook: EFL Teachers' Perspectives. English Language Teaching, 10(3), 26-39. https://doi.org/10.5539/elt.v1on3p26

Nguyen, T. T. T. (2017). Integrating Culture into Language Teaching and Learning: Learner Outcomes. The Reading Matrix, 17(1), 145-155.

Oktavianti., I., Zuliana., E., \& Ratnasari., Y. (2017). Menggagas Kajian Kearifan Budaya Lokal di Sekolah Dasar Melalui Gerakan Literasi Sekolah. [Initiating Local Cultural Wisdom Study in Elementary Schools through School Literacy Movement]. Unpublished Report. Kudus: PGSD-FKIP Universitas Muria Kudus.

Opoku-Amankwa, K., Brew-Hammond, A., \& Kofigah, F. E. (2011). What is in a Textbook? Investigating the Language and Literacy Learning Principles of the "Gateway To English" Textbook Series. Pedagogy, Culture and Society, 19(2), 291-310. https://doi.org/10.1080/14681366.2011.582264

Setyono, B., \& Widodo, H. P. (2019). The Representation of Multicultural Values in the Indonesian Ministry of Education and Culture-Endorsed EFL textbook: A Critical Discourse Analysis. Intercultural Education, 30(4), 383-397. https://doi.org/10.1080/14675986.2019.1548102

Silvia, A. (2015). The Representation of Culture in English Textbooks Prescribed for High Schools in Indonesia. IJEE (Indonesian Journal of English Education), 2(1), 1-16. https://doi.org/10.15408/ijee.v2i1.1432 